\title{
SPECIES DISTRIBUTION UPDATE OF MANSONIA BLANCHARD, 1901 MOSQUITOES (DIPTERA: CULICIDAE) IN INDONESIA WITH THE ILLUSTRATED KEY FOR FEMALE MOSQUITO
}

\author{
Sidiq Setyo Nugroho* ${ }^{1}$, Mujiyono ${ }^{1}$, and Fahmay Dwi Ayuningrum ${ }^{1}$ \\ ${ }^{1}$ Institute for Vector and Reservoir Control Research and Development, Ministry of Health, \\ Jalan Hasanudin 123, Salatiga, Central Java 50721, Indonesia \\ *Corresponding author: sidiqsnugroho148@gmail.com
}

Received: 28 July 2021; Accepted: 13 December 2021; Published: 30 December 2021

\begin{abstract}
Mansonia is a genus of mosquitoes of which several species are confirmed vectors of lymphatic filariasis. Many countries including Indonesia are still struggling to eliminate lymphatic filariasis. Report of the Mansonia mosquito diversity and its distribution is essential to develop the control strategies. Six of eight Mansonia species have been confirmed as lymphatic filariasis vectors in Indonesia. This paper aims to update the distribution of the Mansonia mosquito in Indonesia. Species distribution data were summarized from various literature regarding the Mansonia mosquito. The data is complemented by the results of the National Research on Disease Vector and Reservoir (Rikhus Vektora) results conducted by the National Institute of Health Research and Development (NIHRD) in 2015-2018. There were new distribution records for four species of Mansonia mosquitoes in Indonesia. Mansonia annulata Leicester, Ma. annulifera (Theobald), and Ma. indiana Edwards are now recorded distributed throughout the archipelago. Meanwhile, Ma. bonneae Edwards has a new distribution record in the Moluccas. The illustrated identification key for female Mansonia mosquitoes in Indonesia is provided in this paper.
\end{abstract}

Key words: distribution, Indonesia, Mansonia, mosquito

\section{INTRODUCTION}

The last inclusive checklist of mosquito species in Indonesia was published 40 years ago. The checklist resumed 457 mosquito species in total, and eight of them are in the genus Mansonia (O'Connor \& Sopa, 1981). National attempt to update the mosquito diversity data was realized in National Research on Disease Vector and Reservoir (Rikhus Vektora) held by the National Institute of Health Research and Development (NIHRD), Indonesia Ministry of Health in 2015 to 2018. The research has collected thousands of mosquito specimens from 29 provinces in Indonesia.

Bonne-Wepster (1954) included Mansonioides Theobald and Coquillettidia Dyar as subgenera in genus Taeniorhynchus Lynch Arribalzaga, synonym for Mansonia. Following Ronderos \& Bachmann (1963), Knight \& Stone (1977) treated Mansonia and Coquillettidia as separate genera. Mansonia mosquito, especially subgenus Mansonioides, is generally characterized by: scutal scales at least two colors, scutellar scales always numerous, postspiracular bristles always present, legs with many pale markings, tarsomeres banded with pale scales, wing speckled dorsally with pale and dark broad scales, many of which are strongly asymmetrical, and abdomen intersegmental membranes very strongly spiculate (Belkin, 
1962). In the male, maxillary palpi are longer than the proboscis and turned upwards, with no hair tufts and the terminal segment is minute. The eighth tergite bears a row of stout spines (Wharton, 1962).

The immature stages of Mansonia are commonly found attached to the roots of aquatic plants in ponds, lakes, swamps, marshes, ditches, wells, ground pools, and flood pools in forest swamps (Gass et al., 1982). The larvae of Mansonia resemble those of Coquillettidia in having a sclerotized saw-toothed process at the tip of the siphon, which is modified for piercing submerged parts of aquatic plants to obtain oxygen from the aerenchyma. These larvae have a more sessile habit, hanging head downwards whilst attached to the plant tissues and filtering the water column for food. They are therefore not easily recognized by predators such as fish (Becker et al., 2010).

Genus Mansonia consists of two subgenera, i.e. Mansonia (15 species) and Mansonioides (10 species). Mansonioides is an Old World taxon, with species in the Afrotropical Region (sub-Saharan Africa and Madagascar), Oriental Region, Manchurian Subregion of the Palaearctic and the Australasian Region (Solomon Islands and northward from Queensland, Australia) (Service, 1990; Tanaka et al., 1979; Lee et al., 1988). All of Mansonia species members in Indonesia are included in subgenus Mansonioides (O’Connor \& Sopa, 1981).

Mansonia mosquitoes, especially Mansonioides subgenus, are widely known as vectors for lymphatic filariasis. They are regarded as the nocturnal sub-periodic malayan filariasis in Java (Ma. indiana and Ma. uniformis (Theobald)), Sumatra (Ma. annulata, Ma. bonneae, Ma. dives (Schiner), Ma. indiana, and Ma. uniformis), Kalimantan (Ma. annulata and Ma. uniformis), Sulawesi (Ma. bonneae, Ma. dives, and Ma. uniformis), and Moluccas (Ma. uniformis) (Hoedojo, 1989). Mansonia annulifera is also considered as a major vector for $B$. malayi (periodic) in South Asia region including Indonesia (Ramalingam, 1974; WHO, 2013). The updated distribution data of Mansonia mosquito is essential for vector control efforts, considering the 2025 target for the elimination status of lymphatic filariasis in Indonesia.

Ma. uniformis, a widespread species in the world, is a vector for several viruses such as Bunyamwera, Chikungunya, Spondweni, and Wesselbron (White \& Faust, 2014), in addition to lymphatic filariasis. Converse et al. (1985) reported the isolation of Ingwavuma virus from Ma. uniformis caught in Bintan Island, Sumatra. This paper aims to deliver an update regarding distribution data and provide an illustrated key to aid identification of female Mansonia mosquitoes in Indonesia. 


\section{MATERIALS AND METHODS}

The checklist and distribution data of Mansonia mosquito species in this paper update the checklist of mosquito species in Indonesia created by O'Connor \& Sopa (1981). Species records, distribution data, and taxonomic information were summarized from several references related to the Mansonia mosquitoes and the national research reports of Rikhus Vektora in 2015-2018. Rikhus Vektora was lead by NIHRD in collaboration with local governments, district/city health offices, universities, research institutes, and non-government organizations (NGOs). The research collected mosquito specimens from 87 districts/cities in 29 provinces. However, Mansonia specimens were obtained from 76 districts/cities. This observational research was a cross-sectional study that was conducted for 30 days every year from 2015 to 2018. Each enumerator team, consisting of eight persons, collected data from six designated locations within a district/city during the period of time given. A total of 6,985 specimens collected from the research were reconfirmed in the laboratory to avoid misidentification committed in the field. Identification keys used in the process were Ramalingam (1974) for Oriental mosquitoes, and Lee et al. (1988) for Australasian mosquitoes. The distribution data of the Mansonia mosquito in this paper is limited to the Indonesian region and excludes Malaysian Borneo and Papua New Guinea. The illustrated key was arranged based on the described morphological characters of each species studied from related references.

\section{RESULTS}

The checklist, distribution data and taxonomic remarks of Mansonia mosquito species in Indonesia are presented in Table 1. Indonesia has eight species and all of them are included in the Mansonioides subgenus. Papua has the greatest diversity with seven species. Four species are distributed through the entire archipelago, i.e. Ma. annulata, Ma. annulifera, Ma. indiana, and Ma. uniformis. Mansonia indiana and Ma. septempunctata Theobald were described originally from Indonesia. This paper adds some distribution extension for four Mansonia species in Indonesia. Mansonia annulata is newly recorded from Java, the Lesser Sunda Island (LSI), Moluccas and Papua. Mansonia annulifera distribution is extended to LSI and Moluccas, while Ma. bonneae and Ma. indiana are newly recorded from Moluccas. Distribution of Ma. papuensis (Taylor) in Moluccas now has been deleted and recorded only in Papua. The map of Mansonia species distribution in Indonesia is presented below (Fig. 1). 


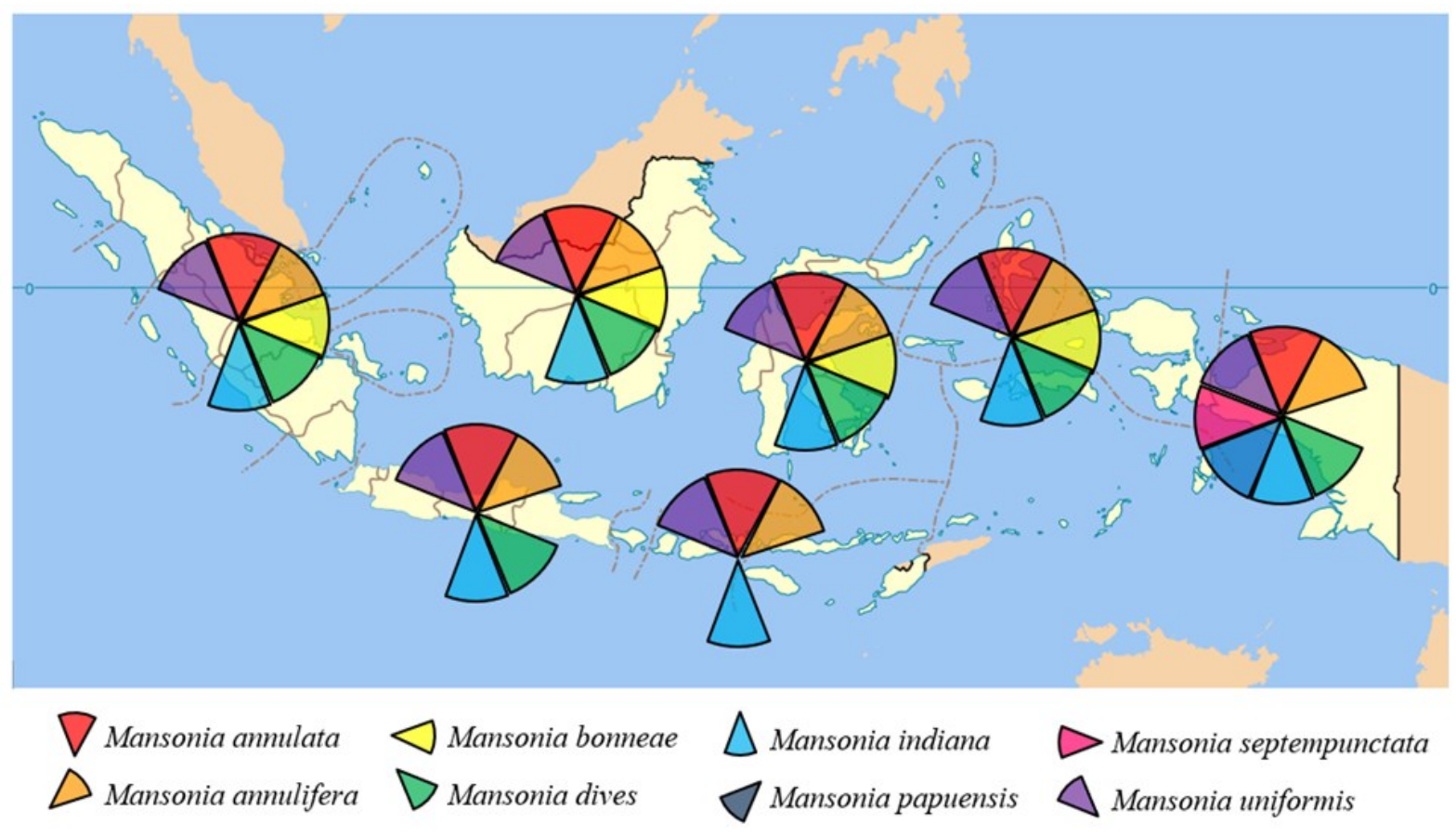

Figure 1. Distribution map of mosquito species of Genus Mansonia in Indonesia.

Table 1. Species checklist and distribution of Mansonia mosquito species in Indonesia

\begin{tabular}{|c|c|c|c|}
\hline Valid species & Synonymy & Geographical distribution & ${ }^{1}$ Remarks \\
\hline $\begin{array}{l}\text { Ma. annulata } \\
\text { Leicester, } 1908\end{array}$ & - & $\begin{array}{l}\text { Sumatra, Kalimantan, Java } \\
\text { LSI }^{1}, \text { Sulawesi, Moluccas } \\
\text { Papua }\end{array}$ & $\begin{array}{l}\text { Newly recorded from } \\
\text { Java, LSI, Moluccas, } \\
\text { and Papua }\end{array}$ \\
\hline $\begin{array}{l}\text { Ma. annulifera } \\
\text { (Theobald, 1901) }\end{array}$ & $\begin{array}{l}\text { Ma. sequini } \\
\text { Laveran } \\
\text { Ma. septemguttata } \\
\text { Theobald }\end{array}$ & $\begin{array}{l}\text { Sumatra, Kalimantan, Java, LSI }{ }^{1} \text {, } \\
\text { Sulawesi, Moluccas }{ }^{1} \text {, Papua }\end{array}$ & $\begin{array}{l}\text { Newly recorded from } \\
\text { LSI and Moluccas }\end{array}$ \\
\hline $\begin{array}{l}\text { Ma. bonneae } \\
\text { Edwards, } 1930\end{array}$ & - & $\begin{array}{l}\text { Sumatra, Kalimantan, Sulawesi, } \\
\text { Moluccas }{ }^{1}\end{array}$ & $\begin{array}{l}\text { Newly recorded from } \\
\text { Moluccas }\end{array}$ \\
\hline $\begin{array}{l}\text { Ma. dives } \\
\text { (Schiner, 1868) }\end{array}$ & $\begin{array}{l}\text { Ma. annulipes } \\
\text { Walker } \\
\text { Ma. longipalpis } \\
\text { van der Wulp }\end{array}$ & $\begin{array}{l}\text { Sumatra, Kalimantan, Java, } \\
\text { Sulawesi, Moluccas, Papua }\end{array}$ & \\
\hline $\begin{array}{l}\text { Ma. indiana } \\
\text { Edwards, } 1930\end{array}$ & - & $\begin{array}{l}\text { Sumatra, Kalimantan, Java*, LSI, } \\
\text { Sulawesi, Moluccas }{ }^{1} \text {, Papua }\end{array}$ & $\begin{array}{l}\text { Newly recorded from } \\
\text { Moluccas }\end{array}$ \\
\hline $\begin{array}{l}\text { Ma. papuensis } \\
\text { (Taylor, 1914) }\end{array}$ & - & Moluceas ${ }^{1}$, Papua & $\begin{array}{l}\text { Distribution record in } \\
\text { Moluccas is deleted }\end{array}$ \\
\hline $\begin{array}{l}\text { Ma. septempunctata } \\
\text { Theobald, } 1905\end{array}$ & $\begin{array}{l}\text { Ma. bonnewepsterae } \\
\text { van den Assem }\end{array}$ & Papua* & \\
\hline $\begin{array}{l}\text { Ma. uniformis } \\
\text { (Theobald, 1901) }\end{array}$ & $\begin{array}{l}\text { Ma. australiensis } \\
\text { Giles } \\
\text { Ma. marquesensis } \\
\text { Dyar } \\
\text { Ma. reversus } \\
\text { Theobald }\end{array}$ & $\begin{array}{l}\text { Sumatra, Kalimantan, Java, LSI, } \\
\text { Sulawesi, Moluccas, Papua }\end{array}$ & \\
\hline
\end{tabular}

Note: *: type locality 


\section{DISCUSSION}

All species records in LSI in this paper are considered new compared to the checklist compiled by O'Connor \& Sopa (1981). Ma. indiana in LSI has been reported by BonneWepster (1954) who found the species in Flores Island. Mansonia uniformis has been reported in Lombok Island (Lee et al., 1988) and Timor Island (Whelan \& Hapgood, 2000). The latest record was reported from Timor Leste, and occurrence of this species in East Nusa Tenggara Province (Indonesia) in the same island is highly possible.

Females of Ma. annulata sometimes bite in swampy jungles during the day. Larvae weres collected from marshy pools near the forest edge (Macdonald, 1957). This species is known as a primary vector for $W$. malayi (Wharton, 1962). Now Ma. annulata has also been recorded from Purworejo and Serang (Java Island), West Lombok (LSI), Central and South Halmahera (North Moluccas Province) and Sarmi (Papua Province) (B2P2VRP, 2015a; B2P2VRP 2015c; B2P2VRP, 2016a; B2P2VRP, 2016c; B2P2VRP, 2016d).

Early record of Ma. annulifera from Papua New Guinea was based on Edwards (1913) erroneous synonymy of the Australasian species Ma. septempunctata with Ma. annulifera. The only other Australasian region record of Ma. annulifera is that of Bonne-Wepster (1938) from Merauke, Irian Jaya, and this may be a misidentification of Ma. septempunctata, which has been recorded (as Ma. bonnewepsterae) as abundant in the area (van den Assem \& van Dijk, 1958). Females of Ma. annulifera are strongly anthropophilic (Bohart, 1945) and greedy biters (Bonne-Wepster, 1954). Horsfall (1955) considered this species a dependable component of the vector for Wuchereria species. Now Ma. annulifera has also been recorded from Jembrana (Bali Island/LSI) and from Central and South Halmahera (North Moluccas Province). Besides, it is confirmed that Ma. annulifera is also distributed in South, Central and North Kalimantan Provinces (B2P2VRP, 2015b; B2P2VRP, 2016c; B2P2VRP, 2017a; B2P2VRP, 2017b; B2P2VRP, 2018).

Bonne-Wepster (1930) recognized a male specimen of Ma. annulipes (now Ma. dives and formerly Ma. longipalpis) which had slightly different male terminalia and described it as Ma. annulipes var. AA. Edwards (1930) found two males in the collection at the British Museum with similar terminalia and designated one from Kuala Lumpur as the type of a new species, Ma. bonneae. Female specimens of the two species were not distinguishable until Edwards suggested that the presence of a small patch of white scales at the side of the scutum just in front of the wing roots would separate Ma. dives from Ma. bonneae (Wharton, 1962). This species has been newly recorded from Aru Islands (Moluccas Province) and Central and South Halmahera (North Moluccas Province) (B2P2VRP, 2016b; B2P2VRP, 2016c). 
The name of Ma. dives has a quite long history. Edwards (1922) previously declared dives to be an unnecessary new name for Culex annulipes Walker. Later, C. annulipes Walker was transferred to the genus Taeniorhynchus (former name Mansonia). Edwards (1930) acknowledged that annulipes Walker was a junior homonym for C. annulipes Meigen (now as Aedes annulipes Meigen) and required a new name. Edwards rejected dives again because specimen described by Schiner for dives was a different species than annulipes Walker. Edwards (1925) had already synonymized longipalpis van der Wulp with annulipes Walker. However, Stone (1957) pointed out that even though Schiner may have misidentified annulipes Walker, dives is a valid substitute name for annulipes Walker and must be applied to that species (Lee et al., 1988).

Edwards (1930) proposed name indiana for Indonesian specimens described by BonneWepster (1930) on the basis of a misidentification by Edwards himself, as Taeniorhynchus africanus. Most authors have continued to include New Guinea in the distribution of $M a$. indiana on the basis Bonne-Wepster's record in Upper Digoel. This paper confirmed that Ma. indiana is indeed distributed in Papua based on species collection in Merauke. This species was also reported from South Halmahera (North Moluccas Province) (B2P2VRP, 2016c).

Mansonia papuensis is known only from New Guinea. Brug \& Bonne-Wepster (1947) listed this species from Seram (Moluccas), but this record is questionable (Lee et al., 1988). There is no report of Ma. papuensis collection from any region in Moluccas, so the authors decided to delete this species distribution in Moluccas. In Irian Jaya, van Dijk (1958) found that larvae of $W$. bancrofti could develop to maturity in Ma. papuensis but the high mortality of experimental mosquitoes made it difficult to assess the susceptibility of this species. $\mathrm{He}$ then concluded that in experimental conditions the development of $W$. bancrofti in Ma. papuensis was a slow and laborious process (Lee et al., 1988).

Adults of Ma. septempunctata are pests, biting after sunset and also in daytime in wet and shady places. In Sentani Lake, they were collected from aquatic plants Pistia stratiotes and Hydrocharis asiatica in a restricted area where the water was proven to be heavily polluted with waste from native houses nearby (van den Assem \& Bonne-Wepster, 1964). Van Dijk in 1958 caught specimens of Ma. septempunctata (in his paper recorded as Ma. longipalpis) on a microfilaria carrier and kept them alive afterwards in test tubes, dissecting the dead ones. In 22 specimens, he estimated 87 percent were infected, but he could not trace infective instars. The development of the microfilariae within the mosquito seemed inhibited in the presausage stage and a subsequent degeneration was noted (van den Assem, 1958). 
Mansonia uniformis distribution is extensive. It is listed by Knight \& Stone (1977) as Ethiopian (Afrotropical), Oriental and Australasian regions east to Bismarcks archipelago, Japan, Ryukyu-Retto. In Indonesia, Ma. uniformis is distributed throughout the archipelago. This species occurs in wet conditions in swampy areas and is certainly one of the most aggressive biters, ready to attack at day or night. They often bite in large numbers indoors at night and bite in the shade during the day (van den Assem, 1959). Mansonia uniformis is an important vector for $W$. bancrofti in areas with large swamps where anopheline mosquitoes are virtually absent (de Rook \& van Dijk, 1959). Brug \& de Rook (1933) stated that Ma. uniformis was hospitable to $W$. malayi in Seram, and it was also highly hospitable to Brugia patei and B. pahangi (Laurence \& Pester, 1961).

Dalilah et al. (2017) reported the collection of Ma. africana in large numbers from Sungai Rengit Murni village in South Sumatra. This report is questionable, because Ma. africana is restricted in distribution to tropical Africa (Laurence, 1960). The author suggested that the species was probably Ma. indiana. Misidentification would likely occur because Ma. africana is closely related to Ma. indiana and Ma. septempunctata (Wharton, 1962). Bonne-Wepster had also misidentified africanus for some females from the Upper Digoel, Irian Jaya. Edwards (1930) then suggested that these specimens were $M a$. septempunctata (Lee et al., 1988).

The role of Mansonia species as lymphatic filariasis vectors has been recorded by Directorate General of Infectious Disease Elimination and Environmental Health (PPM\&PL), Ministry of Health. Mansonia uniformis is competent as a lymphatic filariasis vector in all main islands where they occur. Closest to Ma. uniformis, Ma. indiana was also recorded as vector in Java, Sumatra, Kalimantan and Sulawesi but has never been confirmed from the Moluccas and Papua region. Compared to other species that have entire achipelago distribution, for instance Ma. annulifera, it was only recorded as vector in Sumatra, Kalimantan, and Sulawesi. Meanwhile Ma. annulata was only confirmed as vector in Sumatra and Kalimantan (PPM\&PL, 2008).

In conclusion, Indonesia has eight species of Mansonia mosquitoes that are entirely included in Mansonioides subgenus. The distribution data is updated for the following species: Mansonia annulata (Java, the Lesser Sunda Islands, Moluccas, and Papua), Ma. annulifera (the Lesser Sunda Islands and Moluccas), Ma. indiana and Ma. bonneae (Moluccas). The distribution of Ma. annulifera (Kalimantan) and Ma. indiana (Papua) has been confirmed. Meanwhile, the distribution record of Ma. papuensis in Moluccas has been removed. The identification key of female Mansonia mosquitoes is provided in this paper. 


\section{IDENTIFICATION KEY FOR FEMALE MANSONIA MOSQUITO IN INDONESIA Modification from Ramalingam (1974)}

1. Scutum entirely dark, wing dark scaled, tarsomere without distinct pale bands, small species (Fig. 1a)

papuensis

Scutum with variable ornamentation, wing speckled, larger species (Fig. 1b) 2

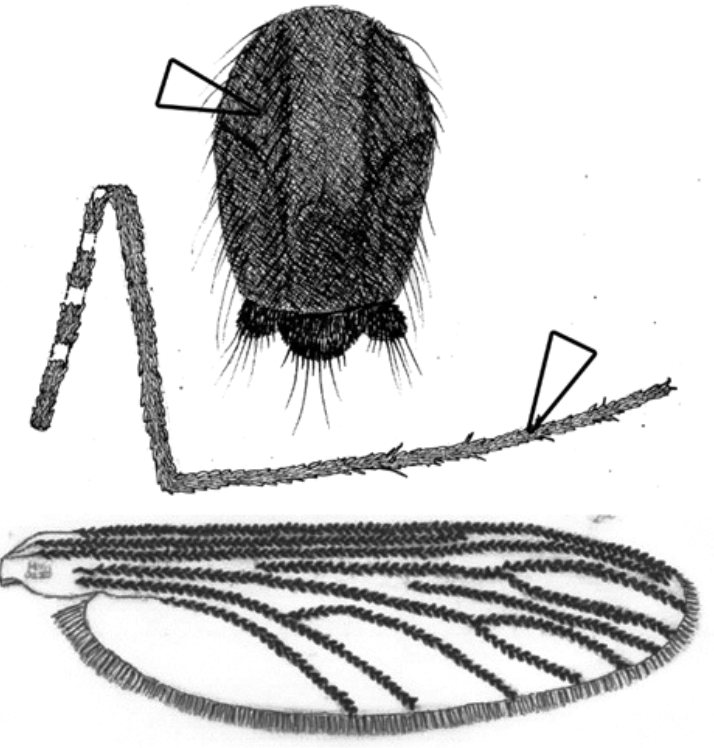

$1 \mathrm{a}$

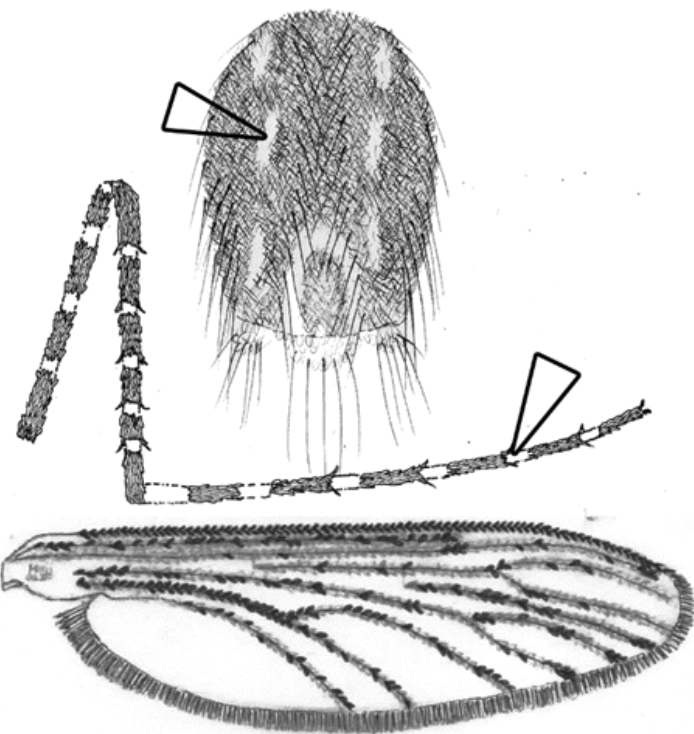

$1 b$

2. Scutum with a pair of pale greenish longitudinal lines, brown colored mosquito (Fig. 2a) uniformis 3
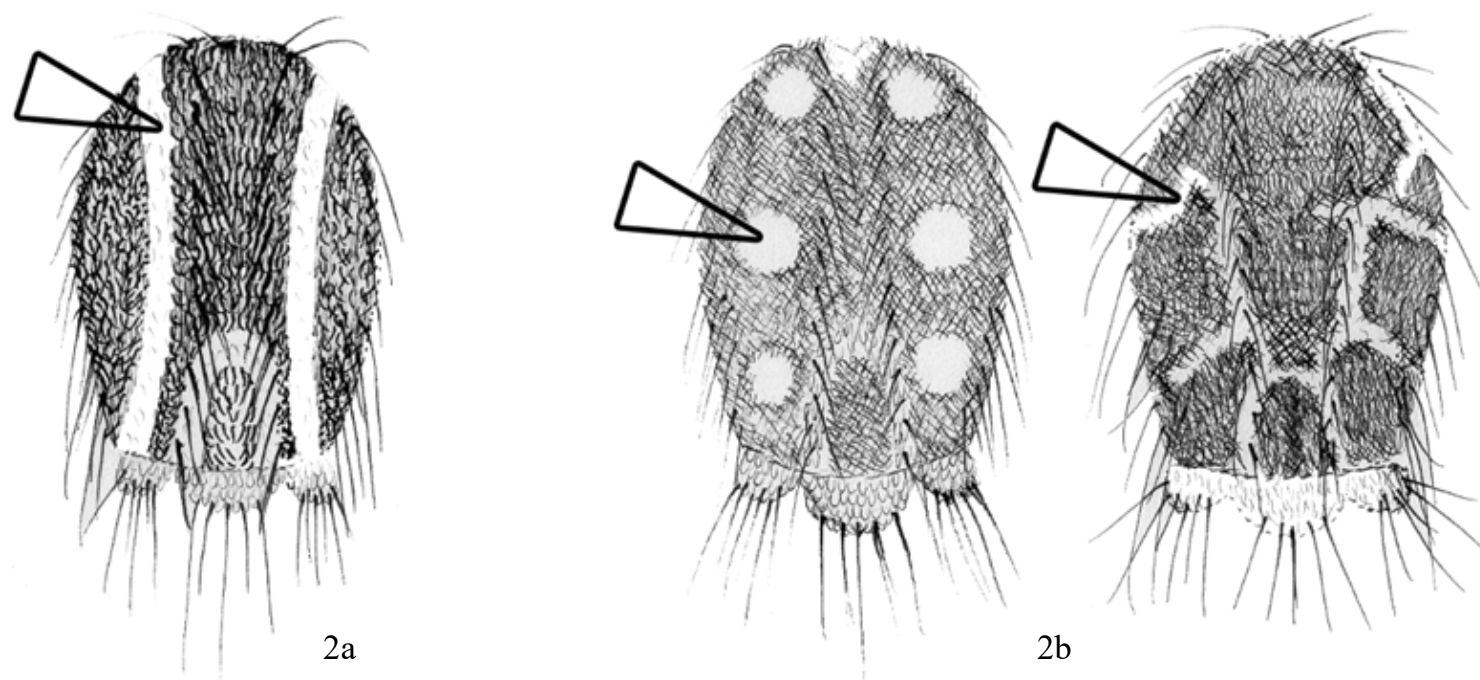

3. Scutum with disctinct and regular round spots of light scales (Fig. 3a) 4 Scutum with irregular patches of pale scales (Fig. 3b) 

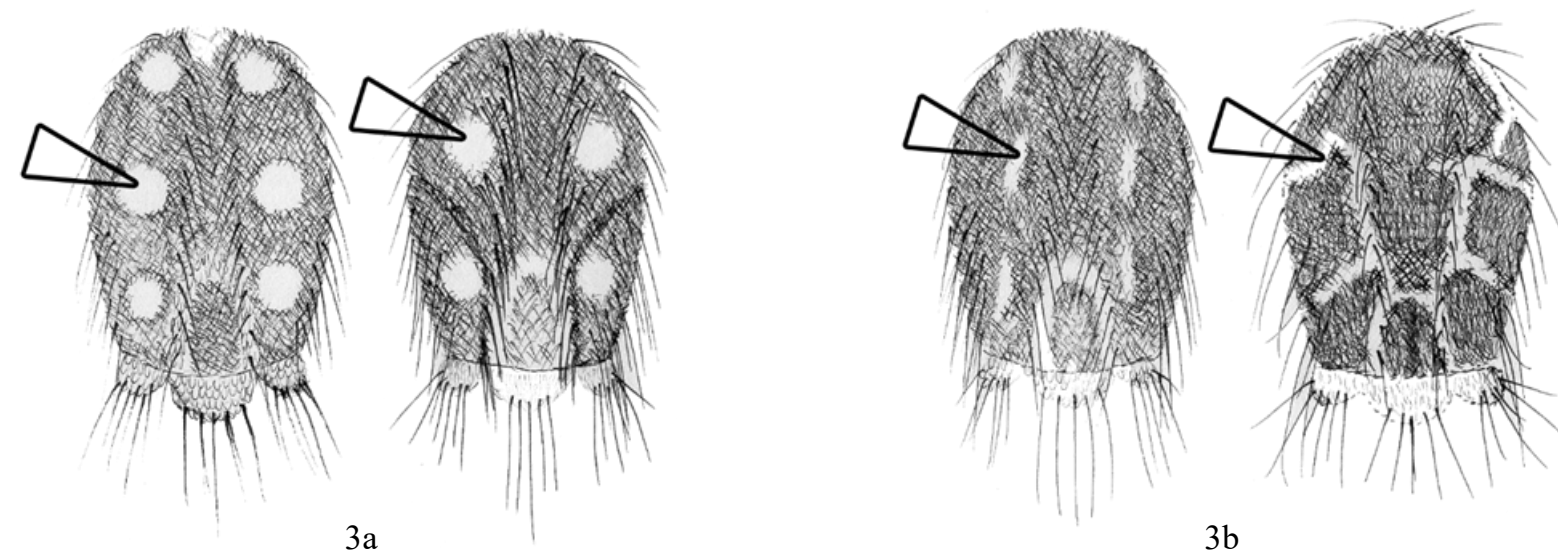

4. Scutum with six distinct silvery spots, midlobe of scutellum with moderately wide flat white scales, small to medium species, pale or yellowish colored mosquito (Fig. 4a)

annulifera

Scutum with four distinct rounded spots of white scales, femur with distinct white bands and scattered pale scales, medium species (Fig. 4b) 5

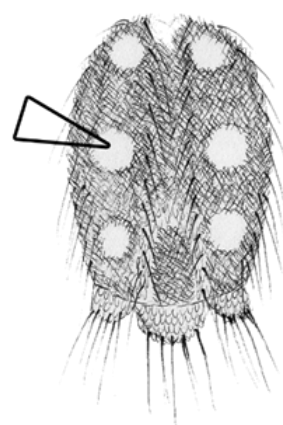

$4 \mathrm{a}$

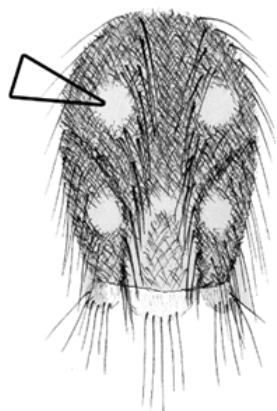

$4 \mathrm{~b}$

5. Fore tibia with $10-15$ scattered small white dots, ventral surface white from base to apex (Fig. 5a) septempunctata

No available specimens

$5 a$

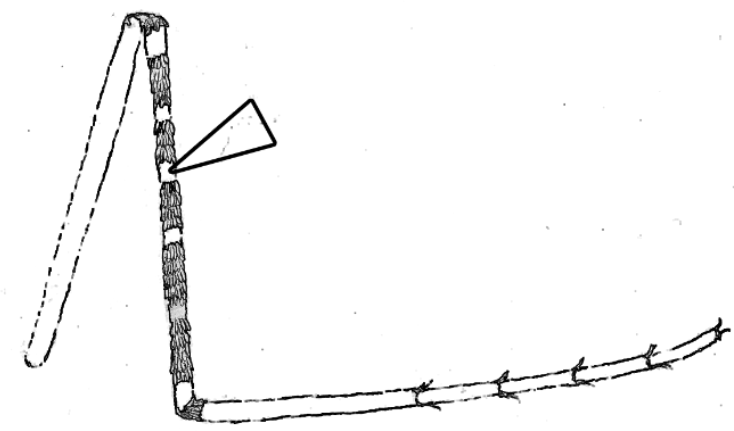

$5 b$ 
6. Supra alar area with wide or curved white scales (Fig. 6a) dives Supra alar area without wide or curved white scales (Fig. 6b)

bonneae

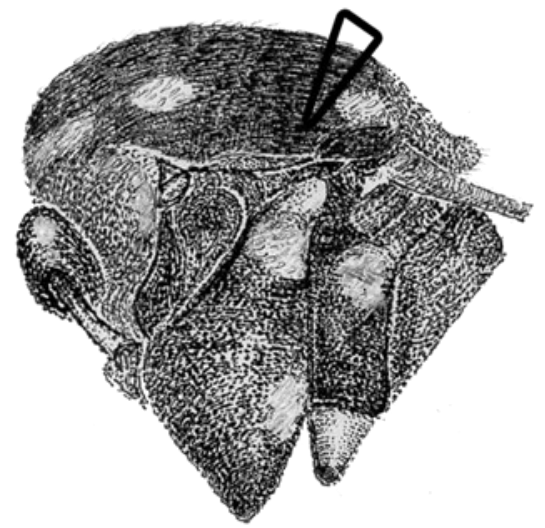

$6 a$

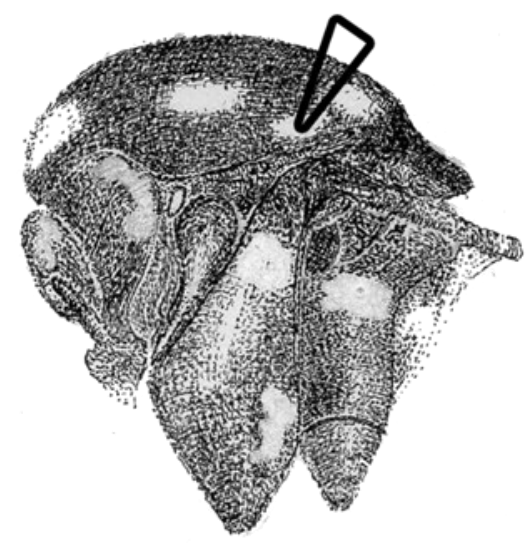

$6 \mathrm{~b}$

7. Hind femur with three distinct pale bands, scutum dark with irregular pattern of narrow yellow scales (Fig. 7a) annulata

Hind femur with about five pale bands, scutum golden-brown with irregular patches of white scales (Fig. 7b)

indiana
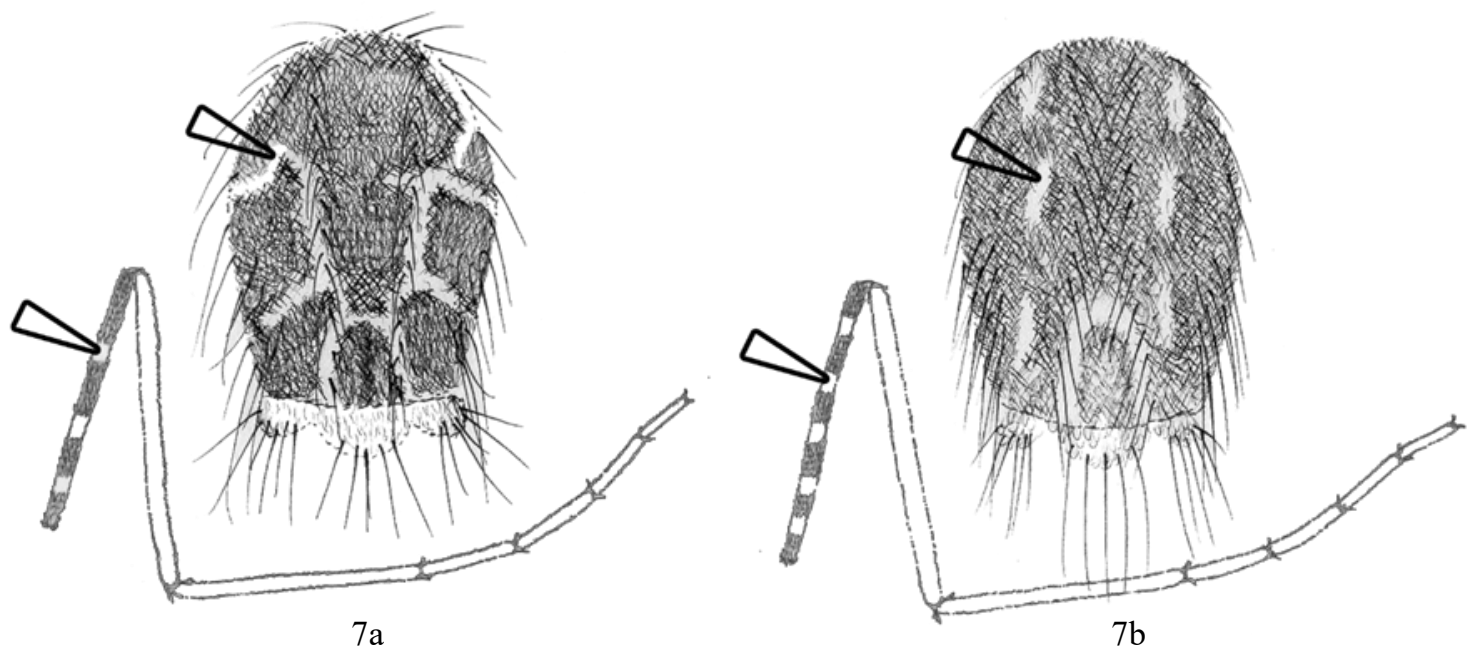

\section{ACKNOWLEDGMENTS}

The authors deliver many thanks to the Head of NIHRD for his permission to utilize data from Rikhus Vektora research reports. Thanks to the Head of Institute for Vector and Reservoir Control Research and Development (IVRCRD) Salatiga who has provided great support so this publication can be presented and completed. The authors also thank to all Rikhus Vektora team for this outstanding scientific work. 


\section{REFERENCES}

B2P2VRP 2015a. Laporan Riset Khusus Vektor dan Reservoir Penyakit: Provinsi Jawa Tengah, Salatiga, 144 $\mathrm{pp}$.

B2P2VRP 2015b. Laporan Riset Khusus Vektor dan Reservoir Penyakit: Provinsi Kalimantan Selatan, Salatiga, $209 \mathrm{pp}$.

B2P2VRP 2015c. Laporan Riset Khusus Vektor dan Reservoir Penyakit: Provinsi Papua, Salatiga, 125 pp.

B2P2VRP 2016a. Laporan Riset Khusus Vektor dan Reservoir Penyakit: Provinsi Jawa Barat, Salatiga, 153 pp.

B2P2VRP 2016b. Laporan Riset Khusus Vektor dan Reservoir Penyakit: Provinsi Maluku, Salatiga, 135 pp.

B2P2VRP 2016c. Laporan Riset Khusus Vektor dan Reservoir Penyakit: Provinsi Maluku Utara, Salatiga, 136 pp.

B2P2VRP 2016d. Laporan Riset Khusus Vektor dan Reservoir Penyakit: Provinsi Nusa Tenggara Barat, Salatiga, $179 \mathrm{pp}$.

B2P2VRP 2017a. Laporan Riset Khusus Vektor dan Reservoir Penyakit: Provinsi Bali, Salatiga, 79 pp.

B2P2VRP 2017b. Laporan Riset Khusus Vektor dan Reservoir Penyakit: Provinsi Kalimantan Tengah, Salatiga, $76 \mathrm{pp}$.

B2P2VRP 2018. Laporan Riset Khusus Vektor dan Reservoir Penyakit: Provinsi Kalimantan Utara, Salatiga, $86 \mathrm{pp}$.

Becker, N., Petric, D., Zgomba, M., Boase, C., Madon, M., Dahl, C. \& Kaiser, A. 2010. Mosquitoes and Their Control. Second ed. Heidelberg: Springer: 577 pp.

Belkin, J.N. 1962. The Mosquitoes of the South Pacific (Diptera, Culicidae). Vol. 1., Los Angeles: University of California Press: 608 pp.

Bohart, R.M. 1945. A synopsis of the Philippine mosquitoes, NAVMED, 580: 1-88.

Bonne-Wepster, J. 1930. The genus Taeniorhynchus (Arribalzaga) in the Dutch East Indies. Mededeelingen van den Dienst der Volksgezondheid in Nederlandsch-Indië, 19: 196.

Bonne-Wepster, J. 1938. Geographic relationship of the non-anopheline mosquitoes of New Guinea. Mededeelingen van den Dienst der Volksgezondheid in Nederlandsch-Indië, 27(1-2): 206-212.

Bonne-Wepster, J. 1954. Synopsis of a Hundred Common non-anopheline Mosquitoes of The Greater and Lesser Sundas, The Moluccas and New Guinea. Royal Tropical Institute Amsterdam. Special publication: Elsevier: 147 pp.

Brug, S. \& de Rook, H. 1933. Filariasis in Nederlandsch-Indie. Geneeskundig tijdschrift voor NederlandschIndie, 73: 264-279.

Brug, S.L. \& Bonne-Wepster, J. 1947. The Geographical Distribution of the Mosquitoes of the Malay Archipelago. Overdruk Uit Chronica Naturae, 103: 1-19.

Converse, J.D., Tan, R.I, Rachman, I.T., Lee, V.H. \& Sophe, R.E. 1985. Ingwavuma virus (Simbu group) from Culex and Mansonia mosquitoes (Diptera: Culicidae) in Indonesia. Journal of Medical Entomology, 22(3): 339-342.

Dalilah, Anwar, C., Theodorus \& Saleh, I. 2017. Identifikasi spesies nyamuk genus Mansonia dan deteksi molekuler terhadap mikrofilaria/larva cacing Brugia malayi pada nyamuk genus Mansonia. Jurnal Kedokteran dan Kesehatan: Publikasi Ilmiah Fakultas Kedokteran Universitas Sriwijaya, 4(2): 69-75.

de Rook, H. \& van Dijk, W. 1959. Changing concept of Wuchereria bancrofti transmission in Netherlands New Guinea. Tropical and Geographical Medicine, 11: 57-60.

Edwards, F.W. 1922. A synopsis of adult Oriental Culicine (including Megarhinine and Sabethine) mosquitoes. Part II. Indian Journal of Medical Research, 10: 430-475.

Edwards, F.W. 1925. Mosquito Notes. -V. Bulletin of Entomological Research, 15: 257-270.

Edwards, F.W. 1913. New synonymy in Oriental Culicidae. Bulletin of Entomological Research, 4: 221-242.

Edwards, F.W. 1930. Mosquito notes. -X. Bulletin of Entomological Research, 21: 541-545.

Gass, R.F., Deesin, T., Surathin, K., Vutikes, S. \& Sucharit, S. 1982. Observations on the feeding habits of four species of Mansonia (Mansonioides) mosquitoes in Southern Thailand. Southeast Asian Journal of Tropical Medicine and Public Health, 13(2): 211-5.

Hoedojo. 1989. Vector of malaria and filariasis in Indonesia. Buletin Penelitian Kesehatan, 17(2): 180-190. 
Horsfall, W.R. 1955. Mosquitoes, Their Bionomics and Relation to Disease. New York: The Ronald Press Company: viii +723 pp. ref. 78 pp.

Knight, K.L. \& Stone, A. 1977. A Catalog of the Mosquitoes of the World (Diptera: Culicidae). Washington: Thomas Say Foundation: 611 pp.

Laurence, B. 1960. The biology of two species of mosquito, Mansonia africana (Theobald) and Mansonia uniformis (Theobald), belonging to the subgenus Mansonioides (Diptera, Culicidae). Bulletin of Entomological Research, 51: 491-517.

Laurence, B. \& Pester, F. 1961. The behaviour and development of Brugia patei (Buckley, Nelson \& Heisch, 1958) in a mosquito host, Mansonia uniformis (Theobald). Journal of Helminthology, 35: 285-300.

Lee, D.J., Hicks, M.M., Debenham, M.L., Griffiths, M., Bryan, J.H. \& Marks E.N. 1988. The Culicidae of the Australasian Region: Genus Culex (Lutzia, Neoculex); Genus Culiseta, Ficalbia, Heizmannia, Hodgesia, Malaya, Mansonia. In: M. Debenham, ed. The Culicidae of the Australasian Region. Vol. 9 (Entomology Monograph No. 2 [part]). Canberra: Australian Government Publishing Service: ix+162 pp.

Macdonald, W.W. 1957. An interim review of the non-Anopheline mosquitoes of Malaya. Malaya, 28: 1-34.

O'Connor, C.T. \& Sopa, T. 1981. A Checklist of the Mosquitoes of Indonesia. NAMRU-SP-4., Jakarta: U.S. Naval Medical Research Unit No. 2 Jakarta, Indonesia: 26 pp.

PPM \& PL. 2002. Epidemiologi Penyakit Kaki Gajah (Filariasis) di Indonesia. Buku 2., Direktorat Jenderal PPM \& PL, Departemen Kesehatan RI, 75 pp.

Ramalingam, S. 1974. A Brief Mosquito Survey of Java. WHO/VBC/74.504, 66 pp.

Ronderos, R.A. \& Bachmann, A.O. 1963. A proposito del complejo Mansonia (Diptera-Culicidae). Revista de la Sociedad Entomologica Argentina, XXV: 43-51.

Service, M.W. 1990. Handbook to the Afrotropical Toxorhynchitine and Culicine Mosquitoes, excepting Aedes and Culex. London: British Museum (Natural History): 207 pp.

Stone, A. 1957. Corrections in the taxonomy and nomenclature of mosquitoes (Diptera, Culicidae). Proceedings of the Entomological Society of Washington, 58(6): 333-344.

Tanaka, K., Mizusawa, K. \& Saugstad, E.S. 1979. A revision of the adult and larval mosquitoes of Japan (including the Ryukyu Archipelago and the Ogasawara Islands) and Korea (Diptera: Culicidae). Contribution of the American Entomological Institute, 16: 1-987.

van den Assem, J. 1958. Mansonia (Mansonioides) bonnewepsterae, spec. nov. (Culicidae) with notes on habits and breeding place. Tropical and Geographical Medicine, 10: 205-212.

van den Assem, J. 1959. Some notes on mosquitoes collected on Frederik Hendrik Island (Netherlands New Guinea). Tropical and Geographical Medicine, 11: 140-146.

van den Assem, J. \& van Dijk, W. 1958. Distribution of anopheline mosquitoes in Netherlands New-Guinea. Tropical and Geographical Medicine, 10(3): 249-55.

van den Assem, J. \& Bonne-Wepster, J. 1964. New Guinea Culicidae, A synopsis of vectors, pests and common species. Zoologische Bijdragen, 6(1): 1-136.

van Dijk, W. 1958. Transmission of Wuchereria bancrofti in Netherlands New-Guinea. Tropical and Geographical Medicine, 10: 21-33.

Wharton, R.H. 1962. The biology of Mansonia mosquitoes in relation to the transmission of filariasis in Malaya. Bulletin - Institute for Medical Research Kuala Lumpur, 11:1-114.

Whelan, P. \& Hapgood, G. 2000. A mosquito survey of Dili, East Timor, and implications for disease control. Arbovirus Research in Australia, 8: 405-416.

White, G.B. \& Faust, C. 2014. Medical Acarology and Entomology. In: J. Farrar, P. Hotez, T. Junghanss, G. Kang, D. Lalloo \& N. White, eds. Manson's Tropical Diseases. Philadelphia: Elsevier Saunders Ltd.: 12581272 .

WHO. 2013. Lymphatic Filariasis: A Handbook for National Elimination Programmes. Geneva: WHO Press: $92 \mathrm{pp}$. 